\title{
Antimicrobial assessment of phage therapy using a porcine model of biofilm infection
}

\author{
C. Milho ${ }^{1}$, M. Andrade ${ }^{1}$, D. Vilas Boas, D. Alves, S. Sillankorva* \\ Centre of Biological Engineering, LIBRO - Laboratório de Investigação em Biofilmes Rosário Oliveira, University of Minho, 4710-057 Braga, Portugal
}

\section{A R T I C L E I N F O}

\section{Keywords:}

Chronic wounds

Porcine skin model

Biofilms

Bacteriophages

\begin{abstract}
A B S T R A C T
Antibiotic resistant bacterial communities persist in many types of wounds, chronic wounds in particular, in the form of biofilms. Biofilm formation is a major cause of severe infections and the main reason for a negative treatment outcome and slow healing progression. Chronic wounds are a silent epidemic essentially affecting people with co-morbid conditions such as diabetes and obesity and elderly persons particularly those with movement limitations. The development of complementary and alternative effective strategies to antibiotics for the treatment of chronic wounds is highly desired. Phage therapy constitutes a very promising approach in the control of topical microbial populations. In this work newly isolated phages were tested for their efficacy to control bacterial species that predominate in chronic wounds. Phage effectiveness was studied on 24-h old biofilms formed in polystyrene microplates and in porcine skin explants using two treatment approaches: individual phage and a cocktail of phages against four main pathogens commonly isolated from chronic wounds. The two models produced variations in the surface colonization ability, assessed by viable bacterial counts and microscopy visualization after using peptide nucleic acid (PNA) or locked nucleic acid probes (LNA) and 2'-Omethyl (2'-OMe) in fluorescence in situ hybridization (FISH), and in the phage-host interactions. Phages alone and combined caused greater reductions in the number of viable cells when biofilms had been formed on porcine skins and with greater variations detected at $4 \mathrm{~h}$ and $24 \mathrm{~h}$ of sampling. These results suggest that porcine skin models should be preferentially used to assess the use of phages and phage cocktails intended for topical use in order to understand the fate, throughout treatment time, of the population when dealing with biofilm-related infections.
\end{abstract}

\section{Introduction}

A wound is an injury to living tissue and depending on the evolution of the healing process, it can be divided into acute and chronic. Acute wounds follow the normal healing process (hemostasis, inflammation, granulation, epithelization, and maturation) (Ammons, 2010), restoring the anatomical and functional integrity of the injured site, as opposed to chronic wounds that remain stagnant in a state of inflammation for a period of six weeks or more (Ammons, 2010; Wolcott et al., 2008a,b). These wounds, that do not follow a timely and orderly healing process of the injured site, represent a silent epidemic that affects a large fraction of the world population and poses a major threat to public health and the economy (Sen et al., 2009). In developed countries, it is estimated that 1 to $2 \%$ of the population will have a chronic wound during their lifetime (Gottrup, 2004), due to the increase in lifestyle diseases such as diabetes, obesity and cardiovascular diseases and also due to the increasing proportion of elderly population (Price et al., 2009; Sen et al., 2009). The chronicity of the wounds is largely due to ischemia (restriction in blood supply) resulting in lack of oxygen in the cells (hypoxia), intrinsic factors of the host, and bacterial infections. The latter are responsible for the inflammation and continuous destruction of the tissues, which limits wound healing (Rhoads et al., 2012; Wolcott et al., 2008a,b).

All wounds are susceptible to infections and development of microbial communities in the wound bed, referred to as biofilms (Percival et al., 2012). Biofilms are a set of microorganisms that aggregate on biotic or abiotic surfaces and grow in community, surrounded by a matrix of extracellular polymer substances (EPS) that microorganisms secrete (Hall-Stoodley and Stoodley, 2009; Stewart and William Costerton, 2001). Biofilms are an important survival strategy of the microorganisms, and their presence in wounds is considered the main reason why venous, pressure and diabetic ulcers progress to chronic

\footnotetext{
* Corresponding author.

E-mail address: s.sillankorva@deb.uminho.pt (S. Sillankorva).

${ }^{1}$ These authors have equally contributed to this work.
} 
conditions, and why they are so difficult to control either by immunological response or by antimicrobial therapy (Percival et al., 2012). The reduced metabolic activity of cells in biofilms is also a survival strategy since metabolically quiescent biofilm cells survive antimicrobials because these agents require energy to eliminate cells (Fux et al., 2005). In addition, the great majority of antimicrobials are designed to act on microorganisms in the exponential growth phase, which makes their use in biofilms impracticable (Mascio et al., 2007).

The microbial flora of chronic wounds changes over time. Grampositive bacteria predominate, in the first phases of an infection, and many of these are common in normal skin flora (e.g. Staphylococcus aureus and $\beta$-hemolytic streptococci such as Streptococcus pyogenes and Streptococcus agalactiae) (Thevanesam, 2013). At a later stage, gramnegative bacteria (e.g. Pseudomonas spp. and Acinetobacter spp.) are the main species present. Long-term wounds are also colonized by anaerobic species, due to the invasion of bacteria into the deeper structures of the tissues (bones and muscles) (Thevanesam, 2013). The most common facultative anaerobic gram-negative bacteria in chronic wounds are Proteus spp., Escherichia coli and Klebsiella spp., which represent between $30 \%$ and $62 \%$ of the total bacteria present (Gjødsbøl et al., 2006; Rhoads et al., 2012). The number of microorganisms required to cause an infection largely depends on the type of microorganisms present, since certain bacteria, in small numbers, produce enzymes that contribute to the debridement of the wound. $S$. aureus, $P$. aeruginosa and $\beta$-hemolytic streptococci are known to cause delayed healing and infection as they produce highly destructive virulence factors (Gooderham and Hancock, 2009; Neves et al., 2018).

Bacterial infection plays an important role in the inability to heal, that can be decreased with appropriate treatments that include suppression of biofilm formation and maturation (Wolcott et al., 2008a,b), and also a biofilm prevention strategy (Thevanesam, 2013). The socioeconomic impact that wounds have on the population requires new treatment strategies that allow healing of these wounds in order to improve human health and reduce treatment costs.

Bacteriophages, also referred to as phages, are bacterial viruses that specifically infect. Phages can be categorised into virulent or temperate depending on their lifecycle. Virulent phages have a replication cycle that ends in the lysis of bacterial host to release the newly formed phage particles and these are the phages suited for therapeutic applications (Sillankorva and Azeredo, 2014). The constant evolution of multiresistant bacteria to antibiotics has motivated the scientific community to reevaluate phage therapy in bacterial infections (Górski et al., 2016). The reimplementation of phage therapy may become a good choice or complementary alternative to commonly used therapeutic drugs, since these are natural antibacterials capable of regulating the growth of exponential and stationary phase cells and can control biofilms (Melo et al., 2016; Oliveira et al., 2017; Oliveira et al., 2018; Pires et al., 2017). Compared with antibiotics, phages have multiple advantages, such as: i) action against multiresistant pathogens; ii) specificity that will consequently not affect the resident cutaneous microflora; iii) low potential for adverse effects not affecting animal cells; iv self-reproducing capacity; v) easy of isolation for the majority of pathogens involved in wound infections; vi) low production cost; and vii) greater effectiveness against stationary and biofilm cells (Oliveira et al., 2015; Pires et al., 2015).

In vitro biofilm models have provided substantial evidence that phages are able to control biofilm populations (Melo et al., 2016; Pires et al., 2011; Sillankorva et al., 2008a). However, biofilm formation on abiotic surfaces, fail in simulating the functional characteristics of biofilms formed in wounds. Notwithstanding that in vivo models are the best to understand wound infection and healing following antimicrobial therapy, there are some ethical and economic constraints associated to their use (Ganesh et al., 2015; Seaton et al., 2015). To overcome these constraints, ex vivo wound models have been developed using animal skin that resemble more closely the characteristics of biofilms formed in this context. These skins provide the surface for microbial attachment and the primary source of their nutrition. (Percival et al., 2012). For instance, Alves et al. (2018) used an ex vivo porcine skin combined with a custom burn wound array device to evaluate the potential of phages to control biofilm formation by Staphylococcus aureus. In a previous study, we used an ex vivo model adapted from da Costa et al., 2015, and this model proved to be suitable for the evaluation of phages alone and combined with honey against mono- and dual species biofilms of $E$. coli and Pseudomonas aeruginosa (Oliveira et al., 2018). However, all these models, including the one we previously used, require fresh porcine skin explants for the experiments demanding controlled skin harvest schedules with the animal research facilities, conducted under strict ethical requirements, which is not always compatible with the research experiments. Furthermore, in our previous model, biofilms were formed on the space between the rubber o-rings and the intact porcine skin explant (see Fig. S1), which better represents a closed type of wound or mild wound such as an abrasion wound. The present model mimics an open wound, where an inicision was made in the epidermis and dermis layers, in order to simulate biofilm formation with proliferation to deeper skin tissue layers (Yang et al., 2013). This ex vivo model provides a more accurate human open skin wound replica to assess biofilm formation and provides a better understanding how these can be controlled using phages, alone and in cocktail against four specific pathogens commonly isolated from infected wounds.

\section{Materials and methods}

\subsection{Bacteria and media}

The clinical isolates used in this study were provided by the Hospital de Braga (Braga, Portugal). In total, 12 strains of Acinetobacter baumannii, 7 strains of $P$. aeruginosa and 31 strains of $E$. coli were used. Also, 2 Proteus mirabilis (SGSC 5460, SGSC 5461) and 2 previously characterized $P$. mirabilis phages (Melo et al., 2016) were used in this study. All strains were grown in TSB medium. The solid medium used was TSA consisting of TSB and $1.5 \%(\mathrm{w} / \mathrm{v})$ agar, and the top agar layer contained TSB and $0.6 \%(\mathrm{w} / \mathrm{v})$ agar. The media were prepared according to the manufacturer's instructions and sterilized $\left(121^{\circ} \mathrm{C}\right.$, $15 \mathrm{~min}$ ). All bacterial strains were preserved in glycerol and stocks maintained at $-80^{\circ} \mathrm{C}$.

\subsection{Verification of the presence of intact temperate phages in bacterial strains}

All strains tested were verified for the presence of temperate phages before use in the enrichment procedures using a procedure previously described (Sillankorva et al., 2010). This verification rules out any false positive results that may interfere in the phage isolation outcomes. Briefly, $100 \mu \mathrm{l}$ of each strain, grown overnight at $37^{\circ} \mathrm{C}$, were mixed with $3 \mathrm{ml}$ of TSA top agar and poured onto a Petri dish containing TSA. The top agar was allowed to solidify and then $20 \mu \mathrm{l}$ drops of all strains of each species were placed on the top agar layer. After the drops had dried, the Petri dishes were incubated overnight at $37^{\circ} \mathrm{C}$ and the presence of lysis zones was evaluated. Effluent enrichment was performed with those bacterial combinations that did not result in lysis areas when spotted in the other tested strains.

\subsection{Phage isolation}

Phage isolation was performed as described previously (Sillankorva et al., 2008b). In brief, raw sewage was collected from a wastewater treatment plant (Frossos, Braga), centrifuged $\left(9000 \times g, 4^{\circ} \mathrm{C}, 10 \mathrm{~min}\right)$ and filtered $(0.45 \mu \mathrm{m}$ pore size) to remove solid particles. The filtered raw sewage $(60 \mathrm{ml})$ was placed in sterile $500 \mathrm{ml}$ flasks with double strength TSB. To this mixture, $50 \mu \mathrm{l}$ of each overnight grown bacteria were added and the flasks incubated at $37^{\circ} \mathrm{C}$ with shaking $(120-180 \mathrm{rpm})$ for $24 \mathrm{~h}$. The enriched effluents were centrifuged 
$\left(9000 \times g, 4^{\circ} \mathrm{C}, 10 \mathrm{~min}\right)$ and the supernatant collected and filtered $(0.2 \mu \mathrm{m})$. The spot test on bacterial lawns was used to assess if the enriched effluents had phages. Briefly, $100 \mu$ l of overnight grown bacteria and $3 \mathrm{ml}$ of top agar were poured on a TSA plate and the top agar layer was allowed to solidify. After, $20 \mu \mathrm{l}$ of the enriched effluent were placed and the drop allowed to dry. The plates were incubated overnight at $37^{\circ} \mathrm{C}$. On the following day, the presence or absence of lysis areas (clear and turbid) on the plate, indicators of presence or absence of phage, respectively, were observed. All positive results were further assessed to isolate phages with varied plaque morphologies and were further streaked thrice to guarantee purity of the phage plaques.

\subsection{Phage propagation and titration}

Phages were amplified using the plate lysis and elution method adapted from Sambrook and Russel (2001) that has been described previously (Sillankorva et al., 2008b). Titration of the phage was performed as described previously (Adams, 1959).

\subsection{Phage host range and selection of phages}

The host range specificity was assessed as described previously using the spot test, spotting up to 1000 -fold diluted phage suspensions (Melo et al., 2016). The plating results were described as: positive (+) when lysis-from-within or as LO when lysis-from-without were observed; and negative $(-)$ when phages were not able to infect the bacterium. The selection of phages for further experiments was based on the host range of phages and infectivity towards the bacteria presenting higher resistances to commonly used antibiotics (see Tables 2-4 for percentages of resistance and Tables S1-S4 for their respective susceptibility to different antibiotics tested).

\subsection{In vitro biofilm formation and infection}

A pre-inoculum $(500 \mu \mathrm{l})$ grown overnight at $37^{\circ} \mathrm{C}(120 \mathrm{rpm})$ was used to inoculate $10 \mathrm{ml}$ of TSB medium until an optical density $\mathrm{OD}_{620}$ between 0.2 and 0.3 was reached, which corresponds to approximately $1 \times 10^{8} \mathrm{CFU} \cdot \mathrm{ml}^{-1}$ of each bacterial strain in study. TSB $(200 \mu \mathrm{l})$ and $1 \mu \mathrm{l}$ of bacterial culture were added to 96-well microplates and incubated at $37^{\circ} \mathrm{C}$, under static conditions during $24 \mathrm{~h}$. After that, the medium was removed and the wells washed twice with PBS $\left(8 \mathrm{~g} \cdot \mathrm{l}^{-1}\right.$ $\mathrm{NaCl}, 0.2 \mathrm{~g} \cdot \mathrm{l}^{-1} \mathrm{KCl}, 0.2 \mathrm{~g} \cdot \mathrm{l}^{-1} \mathrm{~K}_{2} \mathrm{HPO}_{4}, 2.85 \mathrm{~g} \cdot \mathrm{l}^{-1} \mathrm{NaHPO}_{4} \cdot 12 \mathrm{H}_{2} \mathrm{O}$ ) to remove planktonic cells, sonicated for $5 \mathrm{~min}$ using an ultrasound water bath (Sonic model SC-52, UK) operating at $50 \mathrm{kHz}$, serially diluted and plated to determine the number of viable cells (CFUs). For phage infection experiments, after washing with PBS, $100 \mu$ of phage or phage cocktail at different multiplicities of infection (MOI), detailed in Table 1 , were added and the 96 -well plates were incubated at $37^{\circ} \mathrm{C}$

Table 1

Single phage and phage cocktails used in the E. coli, A. baumannii, $P$. aeruginosa, and $P$. mirabilis biofilm control experiments and the respective MOIs used in the experiments.

\begin{tabular}{llll}
\hline $\begin{array}{l}\text { Host }+ \text { reference strain or clinical } \\
\text { isolate nr. }\end{array}$ & Phage & $\begin{array}{l}\text { MOI single } \\
\text { strategy }\end{array}$ & $\begin{array}{l}\text { MOI cocktail } \\
\text { strategy }\end{array}$ \\
\hline E. coli EC7 & EC7a & 100 & 100 \\
& EC7b & - & 1 \\
& EC3a & - & 1 \\
A. baumannii AB2 & P2 & 100 & 100 \\
& P1 & - & 1 \\
P. aeruginosa PA1 & AB7a & - & 1 \\
& PA1 & 100 & 100 \\
P. mirabilis SGSC 5460 & PA4 & - & 1 \\
& Pm5460 & 100 & 100 \\
\hline
\end{tabular}

under static conditions. For control experiments, instead of a phage solution, SM buffer (5.8 $\mathrm{g} \cdot \mathrm{l}^{-1} \mathrm{NaCl}, 2 \mathrm{~g} \cdot \mathrm{l}^{-1} \mathrm{MgSO}_{4} \cdot 7 \mathrm{H}_{2} \mathrm{O}, 50 \mathrm{ml} 1 \mathrm{M}$ Tris, pH 7.5) was added to the wells. After 4 and $24 \mathrm{~h}$ of infection, the phage solution and SM buffer were removed from three treated and three control wells, respectively, and washed twice with $100 \mu \mathrm{l}$ of PBS. After washing, $100 \mu \mathrm{l}$ of saline $(\mathrm{NaCl} 0.9 \%(\mathrm{w} / \mathrm{v})$ ) were added to each well, the microplates were sonicated for $5 \mathrm{~min}$ in an ultrasound water bath (Sonic model SC-52, UK) operating at $50 \mathrm{kHz}$, being the wells also scraped thoroughly to detach the biofilm, serially diluted and plated to determine the amount of CFUs. Control samples were performed with $100 \mu \mathrm{l}$ of SM buffer. Four independent experiments in triplicate were performed.

\subsection{Preparation of the porcine skin}

Porcine skin sheets from the backs of pigs were obtained from a local abbatoir after slaughter and prior to scalding and flaming since this was shown by Yang and colleagues (2013) to destroy the epidermis layer. The skins were immediately sterilized using chlorine gas as described previously (Yang et al., 2013). Briefly, skins were washed with $10 \%(\mathrm{v} / \mathrm{v})$ bleach during $5 \mathrm{~min}$. After this, the skins were placed in a desiccator for $45 \mathrm{~min}$ in the presence of chlorine gas created due to the reaction between $20 \mathrm{ml}$ of acetic acid and $10 \mathrm{ml}$ of commercial grade bleach. The reaction was stopped with $30 \mathrm{ml}$ of $1.6 \mathrm{mM} \mathrm{Na}_{2} \mathrm{CO}_{3}$. Subsequently, skins were washed four times with sterile PBS. The excess of PBS was removed by vacuum aspiration. After, $10 \mathrm{~mm} \times 10 \mathrm{~mm}$ squares were cut with a scalpel with an approximate thickness of 4-6 $\mathrm{mm}$, and using a biopsy punch ( $3.5 \mathrm{~mm}$ diameter) a hole was created in the skin, to mimic more closely a wound, with a depth of approximately $1.5 \mathrm{~mm}$ (Fig. 1). Skin squares were then frozen $\left(-20^{\circ} \mathrm{C}\right)$ until further use.

\subsection{Ex vivo biofilm formation and infection}

A bacterial culture at $\mathrm{OD}_{620}$ between 0.2 and 0.3 was grown as described above, and after this, $10 \mu \mathrm{l}$ of this culture was added in the hole, previously created using the biopsy punch, of each skin. The skin explants were put on TSA plates with $0.5 \%(\mathrm{w} / \mathrm{v})$ agar and incubated during $24 \mathrm{~h}$ at $37^{\circ} \mathrm{C}$ with $5 \% \mathrm{CO}_{2}$ and saturated humidity. The explants were washed twice with PBS to remove loosely adhered cells and put in a $15 \mathrm{ml}$ tube with $5 \mathrm{ml}$ of PBS, sonicated ( $30 \mathrm{~s}, 20 \mathrm{~W}$ ), and serially diluted and plated to quantify CFUs before phage challenge. For the phage infection experiments, after washing, each skin was placed in a 24-well plate with either $1 \mathrm{ml}$ of a single phage or $1 \mathrm{ml}$ of a phage cocktail ( 2 to 3 phages, depending on the tested species) using the MOIs detailed in Table 1 . The 24 -well plates were incubated at $37^{\circ} \mathrm{C}$ under static conditions, and after, three treated and three control skin samples were removed at 4 and $24 \mathrm{~h}$. These skins were washed twice with PBS, sonicated $(30 \mathrm{~s}, 20 \mathrm{~W})$, serially diluted and plated to quantify the amount of CFUs. Control experiments were performed using $100 \mu \mathrm{l}$ of SM buffer without phages. Six independent experiments in triplicate were performed for E. coli, and five for A. baumannii, P. aeruginosa and P. mirabilis.

\subsection{Hystological sectioning of porcine skins}

Biofilms in porcine skins were fixed with $4 \%(\mathrm{v} / \mathrm{v})$ paraformaldehyde and stored at $4{ }^{\circ} \mathrm{C}$ for $24 \mathrm{~h}$ until histological processing. Porcine skins were placed in cassettes, dehydrated, paraffin wax-embedded, cut into 3-5 $\mu \mathrm{m}$ sections (HM 325, Microm, Walldorf, Germany) and placed in microscopy slides (Histobond, Raymond A Lamb, Eastbourne, UK). Before hybridization with different probes, microscope slides were dewaxed and hydrated adapting a previously described protocol (Cerqueira et al., 2011). In brief, sections were immersed in xylol, ethanol and water, allowed to air dry, and then were subjected to the hybridization (Almeida et al., 2009; Vilas Boas et al., 2016). 
Table 2

Lytic spectrum of the isolated phages against $E$. coli clinical isolates.

\begin{tabular}{|c|c|c|c|c|c|c|c|c|c|}
\hline \multirow{2}{*}{$\begin{array}{c}\text { Clinical } \\
\text { isolate }\end{array}$} & \multirow{2}{*}{ Origin } & \multirow{2}{*}{ Antibiogram ${ }^{\mathrm{a}}$} & \multicolumn{7}{|c|}{ Phages } \\
\hline & & & EC1 & EC3a & EC3b & EC7a & EC7b & EC9 & EC20 \\
\hline $\mathrm{EC} 1$ & Urine & 6.7 & + & - & - & - & - & - & - \\
\hline $\mathrm{EC} 2$ & Urine & 0.0 & + & LO & LO & LO & LO & LO & - \\
\hline $\mathrm{EC} 3$ & Blood & 6.7 & + & + & + & + & + & + & + \\
\hline EC4 & Urine & 0.0 & + & - & - & - & - & - & - \\
\hline EC5 & $\mathrm{PF}$ & 0.0 & - & - & - & - & - & LO & - \\
\hline EC6 & Urine & 20.0 & - & - & - & - & - & - & - \\
\hline EC7 & Urine & 6.7 & + & + & + & + & + & + & + \\
\hline EC8 & Urine & 0.0 & + & + & + & + & + & + & - \\
\hline EC9 & Urine & 6.7 & - & - & - & - & + & + & + \\
\hline EC10 & Urine & 26.7 & - & - & - & - & - & - & - \\
\hline EC11 & Catheter & 6.7 & - & - & - & - & - & - & - \\
\hline $\mathrm{EC} 12$ & Urine & 13.3 & - & LO & + & LO & LO & - & - \\
\hline EC13 & PF & 60.0 & - & - & - & - & - & LO & LO \\
\hline EC14 & Blood & 60.0 & LO & LO & LO & LO & LO & LO & - \\
\hline EC15 & Urine & 0.0 & + & - & + & - & - & - & - \\
\hline EC16 & Blood & 13.3 & - & - & - & - & - & - & - \\
\hline EC17 & PF & 26.7 & + & - & - & - & - & - & - \\
\hline EC18 & Urine & 6.7 & - & - & - & - & - & - & - \\
\hline EC19 & Urine & 0.0 & + & + & + & LO & LO & LO & - \\
\hline EC20 & Blood & 20.0 & + & + & + & + & - & - & + \\
\hline $\mathrm{EC} 21$ & Urine & 6.7 & - & - & - & - & - & - & - \\
\hline EC22 & Urine & 0.0 & + & - & + & LO & - & - & + \\
\hline EC23 & Urine & 20.0 & + & + & LO & + & + & LO & LO \\
\hline EC24 & Blood & 0.0 & + & - & - & - & - & - & - \\
\hline EC25 & Urine & 0.0 & + & - & - & - & - & - & - \\
\hline EC26 & Urine & 13.3 & - & - & - & - & - & - & - \\
\hline EC27 & Urine & 0.0 & - & - & - & - & - & - & - \\
\hline EC28 & Urine & 20.0 & - & - & - & - & - & - & - \\
\hline EC29 & Urine & 6.7 & - & LO & - & LO & LO & - & - \\
\hline EC30 & Urine & 0.0 & - & LO & - & LO & LO & - & - \\
\hline EC31 & Urine & 6.7 & - & + & + & + & + & + & + \\
\hline Infection (\%) & & & 48,4 & $\mathbf{3 8 , 7}$ & 38,7 & 41,9 & 38,7 & 35,5 & 25,8 \\
\hline
\end{tabular}

PF Peritoneal fluid; (+) Presence of phage plaque; $(-)$ Absence of phage plaque; LO: Lysis from without;

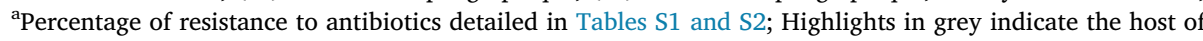
the different phages.

\subsection{Hybridization of samples for microscopy imaging}

Different types of probes were used for the Fluorescence in situ hybridization (FISH) procedure performed on biofilms according to the available types already in our Centre. Peptide Nucleic Acid (PNA) probes were used for $E$. coli and $P$. mirabilis while for $A$. baumannii and $P$. aeruginosa Locked Nucleic Acid (LNA) and 2'-O-methyl probes (2'$\mathrm{OMe}$ ) (see Table S5 for details). Histological sections were covered either with $50 \mu \mathrm{l}$ of PNA hybridization $(10 \%(\mathrm{w} / \mathrm{v})$ dextran sulphate, $10 \mathrm{mM} \mathrm{NaCl}, 30 \%$ (v/v) formamide, $0.1 \%(\mathrm{w} / \mathrm{v}$ ) sodium pyrophosphate, $0.2 \%(\mathrm{w} / \mathrm{v})$ polyvinylpyrrolidone, $0.2 \%(\mathrm{w} / \mathrm{v})$ FICOLL, $5 \mathrm{mM}$ disodium EDTA, $0.1 \%(\mathrm{v} / \mathrm{v})$ Triton $\mathrm{X}-100$ and $50 \mathrm{mM}$ Tris- $\mathrm{HCl}$, and $200 \mathrm{nM}$ of probe) or $50 \mu \mathrm{l}$ of LNA hybridization solution $(900 \mathrm{mM} \mathrm{NaCl}$, $30 \%(\mathrm{v} / \mathrm{v})$ formamide, $20 \mathrm{mM}$ Tris- $\mathrm{HCl}(\mathrm{pH} 7.2), 0.01 \%(\mathrm{w} / \mathrm{v})$ sodium dodecyl sulfate, and $200 \mathrm{nM}$ of probe). Samples were covered with coverslips, placed in Petri dishes with a moist absorbent paper,

Table 3

Lytic spectrum of phages isolated against clinical isolates of $A$. baumannii.

\begin{tabular}{|c|c|c|c|c|c|c|c|c|c|c|c|}
\hline \multirow{2}{*}{ Isolate } & \multirow{2}{*}{\multicolumn{2}{|c|}{ Origin Antibiograma }} & \multicolumn{7}{|c|}{ Phages } & \multirow[b]{2}{*}{$\mathbf{P 1}^{\mathrm{b}}$} & \multirow[b]{2}{*}{$\mathbf{P} 2^{{ }^{b}}$} \\
\hline & & & AB1 & AB3 & AB6a & AB6b & AB7a & $\mathbf{A B} 7 \mathbf{b}$ & AB8 & & \\
\hline $\mathrm{AB} 1$ & $\mathrm{BA}$ & 75.0 & + & + & + & + & + & + & + & & \\
\hline AB2 & Sputum & 37.5 & - & - & - & - & - & - & - & & \\
\hline AB3 & BA & 75.0 & + & + & + & + & + & + & + & & \\
\hline AB4 & Urine & 0.0 & - & - & - & - & - & - & - & & \\
\hline AB5 & Urine & 0.0 & - & - & - & - & - & - & - & & \\
\hline AB6 & BA & 75.0 & + & + & + & + & + & + & + & & \\
\hline AB7 & BA & 75.0 & + & + & + & + & + & + & + & + & + \\
\hline AB8 & Urine & 37.5 & + & + & + & + & + & + & + & & \\
\hline AB9 & Sputum & 0.0 & - & - & - & - & - & - & - & & \\
\hline AB10 & Urine & 37.5 & + & + & + & + & + & + & + & & \\
\hline AB11 & Sputum & 0.0 & - & - & - & - & - & - & - & & \\
\hline $\mathrm{AB} 12$ & SE & 50.0 & - & - & - & - & - & - & - & & \\
\hline $\begin{array}{c}\text { Infection } \\
(\%)\end{array}$ & & & 50 & 50 & 50 & 50 & 50 & 50 & 50 & & \\
\hline
\end{tabular}

BA Bronchial aspirate; SE Skin exudate; (+) Presence of phage plaque; (-) Absence of phage plaque; LO: Lysis from without; ${ }^{\mathrm{a}}$ Percentage of resistance to the antibiotics detailed in Table S3. ${ }^{\mathrm{b}}$ Only tested for the strain AB7. Highlights in grey indicate the host of the different phages. 
Table 4

Lytic spectrum of the isolated phages against $P$. aeruginosa clinical isolates.

\begin{tabular}{ccccccc}
\hline \multirow{2}{*}{ Clinical isolate } & \multirow{2}{*}{ Origin } & \multirow{2}{*}{ Antibiogram $^{\mathbf{2}}$} & \multicolumn{5}{c}{ Phages } \\
\cline { 4 - 7 } & & & PA1 & PA4 & PA6 & PA7 \\
\hline PA1 & Cutaneous & 0.0 & + & - & - & - \\
PA2 & Sputum & 14.3 & LO & - & - & - \\
PA3 & Sputum & 7.1 & LO & + & + & + \\
PA4 & Urine & 7.1 & + & + & + & + \\
PA5 & Urine & 42.9 & - & + & - & + \\
PA6 & Urine & 42.9 & + & + & + & + \\
PA7 & Sputum & 0.0 & + & + & + & + \\
\hline Infection (\%) & & & $\mathbf{8 5 . 7}$ & $\mathbf{7 1 . 4}$ & $\mathbf{5 7 . 1}$ & $\mathbf{7 1 . 4}$ \\
\hline
\end{tabular}

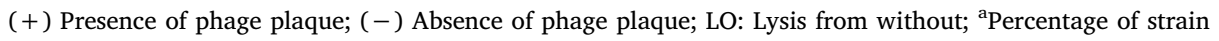
resistance to the antibiotics detailed in Table S4. Highlights in grey indicate the host of the different phages.

wrapped in aluminium foil and incubated at a hybridization temperature of $59^{\circ} \mathrm{C}$ for $90 \mathrm{~min}$ (Almeida et al., 2009; Vilas Boas et al., 2016). After, the coverslip was removed and slides washed with pre-heated specific wash solutions (WS) during $30 \mathrm{~min}$ at $59^{\circ} \mathrm{C}$ to remove unbound probes. The WS used had different composition according to the type of probe used: for PNA probes the WS contained $5 \mathrm{mM}$ Tris Base, $15 \mathrm{mM}$ $\mathrm{NaCl}, 1 \%(\mathrm{v} / \mathrm{v})$ Triton-X while for LNA probes the WS was $20 \mathrm{mM}$ Tris$\mathrm{HCl}(\mathrm{pH} 7.2), 0.01 \%$ SDS (v/v) and $900 \mathrm{mM} \mathrm{NaCl}$.

To visualize biofilms formed on polystyrene surfaces, 24-well microplates were washed with PBS and biofilms fixed to the polystyrene adding $4 \%(\mathrm{v} / \mathrm{v})$ paraformaldehyde during $30 \mathrm{~min}$. After, the paraformaldehyde was removed, samples washed with $50 \%$ ethanol (v/v) and allowed to air dry at room temperature. The wells were then cut with a heated scalpel $(1 \mathrm{~cm} \times 1 \mathrm{~cm}$ squares $)$ and the hybridization procedure was then carried out as described above.

\subsubsection{Microscopy imaging of biofilms on porcine skin and polystyrene}

After the hybridization process, samples were washed, and allowed to air dry in the dark, mounted with one drop of non-fluorescent immersion oil (Merck) and covered with coverslips. Porcine tissues were stained with $50 \mu \mathrm{l}$ of a $1 \mu \mathrm{g} / \mathrm{ml}$ solution of 4', 6-diamidino-2-phenylindole (DAPI) during $10 \mathrm{~min}$, in the dark, and allowed to dry for $5 \mathrm{~min}$. Microscopy imaging was performed using an epifluorescence microscope (Olympus BX51) coupled with a DP71 digital camera and three sets of filters (DAPI - 365-370/421; FITC - 470-490/516; and TRITC 530-550/591) (Olympus Portugal SA, Porto, Portugal). All images were acquired using the Olympus Cell-B software.

\subsection{Statistical analysis}

Statistical analysis of the results was performed using GraphPad Prism 6. Mean and standard deviations (SD) were determined for the independent experiments and the results were presented as mean \pm SD. Results within samples were compared using two-way ANOVA, with Tukey's multiple comparison statistical test. Differences were considered statistically different if $\mathrm{p} \leq 0.05$ (95\% confidence interval). Results between surfaces were compared determining the $p$ value using the multiple $t$ tests program if GraphPad Prism 6 and statistical significance was determined using the Holm-Sidak methos with an alpha of 0.05 .

\section{Results}

\subsection{Presence of intact temperate phages}

A few spotted $P$. aeruginosa clinical isolates resulted in lysis areas indicating microbial growth inhibition and, therefore, were not used for the effluent enrichment procedures. No lysis areas were observed for the E. coli and A. baumannii strains used (data not shown).

\subsection{Lytic spectra}

Lytic spectra of all isolated phages were performed to select the phages for posterior use in the control of biofilms. The criteria used for this selection were host spectrum and the ability to infect the strains showing highest antibiotic resistance. Antibiograms of each strain are detailed in Tables S1-S4. The phages were named according to the bacterial strain from which they were isolated (for example, phage EC2 was isolated from E. coli (EC) clinical isolate number 2). Phage plaques with different morphologies obtained from an isolate were named after the isolation host to which was added a letter at the end, e.g. phage EC3a.

For E. coli, 7 phages were isolated using the clinical isolates. According to Table 2, phage EC1 was able to infect the largest number
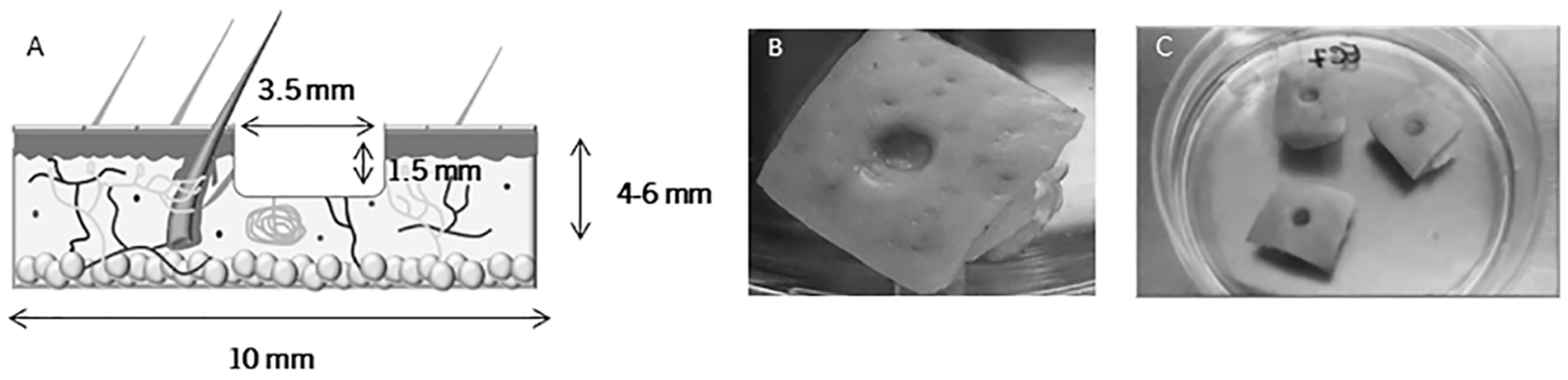

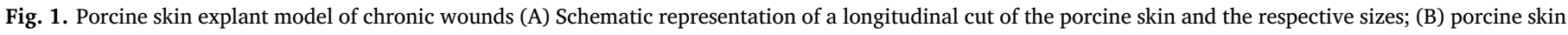
before use; (C) Petri dish with solid TSB media (1.2\% agar) containing three porcine skins after 24 h of incubation with bacteria (E. coli). 
of strains, 48.4\%, while phage EC20 had the narrowest lytic spectrum, infecting only $25.8 \%$ of the strains tested. Lysis of some strains was due to lysis from without (LO), e.g. EC5, EC13, EC14, EC29 and EC30. This list of strains includes two clinical isolates showing $60 \%$ resistance to 15 antibiotics, isolates EC13 and EC14, respectively (see Table S2). Eight of the isolates, presenting antibiotic resistance between 0 (completely sensitive, isolate EC10) to $26.7 \%$ (EC27), were not infected by any phage, not even due to LO. Although phage EC1 infected the highest number of bacterial strains, its production revealed to be very challenging and the successive productions performed resulted in maximum titers below the necessary for further experiments and therefore this phage was discarded from further experiments. Phage EC3a has been previously characterized (Oliveira et al., 2017) and presents clear plaques $(2.63 \mathrm{~mm}$ in diameter) surrounded by a halo [total plaque size (plaque + halo) $=11.55 \mathrm{~mm}$ ]. Morphology and genomic characterization of EC3a showed that it belongs to the Siphoviridae family. Contrarily to this phage, phages EC7a and EC7b, do not present halo and both formed clear plaques that were $2.20 \pm 0.05 \mathrm{~mm}$ and $2.75 \pm 0.25 \mathrm{~mm}$ in diameter, respectively.

Seven phages were isolated for A. baumannii, and their efficacy tested in 12 clinical isolates (Table 3). Regardless of the resistance to different antibiotics (see Table S3), all isolated phages infected the same A. baumannii isolates - $\mathrm{AB} 1, \mathrm{AB} 3, \mathrm{AB} 6, \mathrm{AB} 7, \mathrm{AB} 8$, and $\mathrm{AB} 10$, respectively. All other isolates were not infected, not even due to $\mathrm{LO}$. The phage presenting the highest plaque and halo was AB7. Since there was no difference in lytic spectra, two previously isolated and characterized phages - Podoviridae phages P1 and P2 that have shown to infect strains from the $A$. calcoaceticus - A. baumannii complex (Oliveira et al., 2017) were tested only on bacterial lawns of AB7. Both phages formed clear plaques on these lawns and were, together with phage AB7a, chosen for the experiments using a phage cocktail. Phage AB7a presents a clear plaque that only increases until $24 \mathrm{~h}$, reaching a diameter of $5.00 \pm 0.35 \mathrm{~mm}$ surrounded by a halo that increased every day. At day 1 the diameter of the plaque + halo was approximately $1.2 \mathrm{~cm}$ and by day 5 this diameter was already of $2.8 \mathrm{~cm}$. The plaque characteristics of the other phages have already been described (Oliveira et al., 2017).

For $P$. aeruginosa, 4 phages were isolated and their lytic spectrum was tested against 7 clinical isolates (Table 4). Phage PA1 infected the highest number of tested strains, $85.7 \%$, 2 of which due to LO, followed by phages PA4 and PA7, which infected $71.5 \%$ of the strains. All phages infected the clinical strain (PA6), showing $42.9 \%$ resistance towards the antibiotics tested, while only PA4 and PA7 were capable of infecting the strain PA5, that also presented $42.9 \%$ resistance. Phages PA1 and PA4 were selected for the cocktail approach and their plaques characterized morphologically. Phage PA1 had very small clear plaques with $1.3 \pm 0.10 \mathrm{~mm}$ in diameter, and phage PA4 presented clear plaques but larger in diameter $(2.2 \pm 0.25 \mathrm{~mm})$.

The P. mirabilis phages used, Pm5460 and Pm5461, have been previously characterised and belong to the Podoviridae and Myoviridae families, respectively (Melo et al., 2016).

\subsection{Biofilm control}

In this work, E. coli, P. aeruginosa, A. baumannii, and P. mirabilis biofilms were formed on polystyrene microplates and porcine skins. Infection was performed using a single phage or a phage cocktail containing 2 or 3 phages (Table 1 ), and samples were evaluated after $4 \mathrm{~h}$ and $24 \mathrm{~h}$ of infection.

In $E$. coli experiments, the control surfaces (non-phage treated surfaces) taken at $4 \mathrm{~h}$ and $24 \mathrm{~h}$ showed an 0.8 and $3.0 \log \mathrm{CFU} \cdot \mathrm{cm}^{-2}$ statistically higher $(\mathrm{p}<0.005$, and $\mathrm{p}<0.05$, respectively) colonization of porcine skins compared to polystyrene (see differences in control columns in Fig. 2). Both single phage EC7a and the phage cocktail applied to biofilms formed on porcine skins led to significant reductions ( $\mathrm{p}<0.05)$. Maximum cells reductions at $4 \mathrm{~h}$ and $24 \mathrm{~h}(1.9$ and $2.3 \mathrm{log}$
$\mathrm{CFU} \cdot \mathrm{cm}^{-2}$ ) were obtained with EC7a alone but these were not statistically significant $(p>0.05)$ from the ones obtained with the phage cocktail. Phage control of biofilms formed on polystyrene showed lower cell reduction by phages which varied between reduction of 0.8 and $1.0 \mathrm{CFU} \cdot \mathrm{cm}^{-2}$ after $4 \mathrm{~h}$ and reductions of 1.4 and $1.1 \mathrm{CFU} \cdot \mathrm{cm}^{-2}$ after $24 \mathrm{~h}$ using EC7a alone and the phage cocktail, respectively (Fig. 2).

A. baumannii colonized control porcine skins had slightly more cells than the polystyrene microplates but these differences were not statistically significant $(\mathrm{p}>0.05)$. At $4 \mathrm{~h}$ of infection of biofilms formed on porcine skin, a significant reduction $(\mathrm{p}<0.05)$ of viable cells using AP2 phage (1.4 log CFU $\cdot \mathrm{cm}^{-2}$ reduction) and using the phage cocktail (2.2 log CFU. $\mathrm{cm}^{-2}$ reduction) were observed compared to control samples. Furthermore, treatment with the phage cocktail was significantly better $(\mathrm{p}<0.05)$ than with phage AP2 alone (Fig. 3). At $24 \mathrm{~h}$ of infection, both phage AP2 alone and the phage cocktail led to nonsignificant decreases with cell counts comparable to those obtained for control samples $(\mathrm{p}>0.05)$ due to a great increase of cells from $4 \mathrm{~h}$ to $24 \mathrm{~h}$ of treatment. On polystyrene, the application of both single phage and the phage cocktail had similar effects with somewhat low reductions which fall below $1.0 \log \mathrm{CFU} \cdot \mathrm{cm}^{-2}$ at all tested conditions. No major difference was observed between the two time points $(4 \mathrm{~h}$ and $24 \mathrm{~h}$ ), respectively. A. baumannii phages were more successful in controlling biofilms formed in porcine skin samples than in the polystyrene surface, however only during a short treatment period.

$P$. aeruginosa colonization was significantly higher in porcine skin than in polystyrene being the difference in cell levels of 0.4 and $2.4 \mathrm{log}$ $\mathrm{CFU} \cdot \mathrm{cm}^{-2}$ at $4 \mathrm{~h}$ and $24 \mathrm{~h}(\mathrm{p}<0.05$ at $4 \mathrm{~h}$ and $\mathrm{p}<0.001$ at $24 \mathrm{~h}$ ), respectively. Both phage PA1 alone and the phage cocktail reduced significantly $(\mathrm{p}<0.05)$ the levels of $P$. aeruginosa present on porcine skins at $4 \mathrm{~h}$, however, only PA1 alone was also able to reduce significantly $(\mathrm{p}<0.05)$ at $24 \mathrm{~h}$ of infection (Fig. 4). At $24 \mathrm{~h}$, the phage cocktail consisting of two phages (phages PA1 and PA4) was ineffective in killing $P$. aeruginosa from porcine skins, resulting in bacterial loads similar to those observed in the controls. On the other hand, P. aeruginosa biofilms grown on polystyrene were equally infected by the single phage and the phage cocktail. However, both of these strategies led to only slight reductions in viable cells, which were not statistically significant compared to the control samples ( $\mathrm{p}>0.05)$.

P. mirabilis experiments showed a $1.0 \mathrm{log} \mathrm{CFU} \cdot \mathrm{cm}^{-2}$ statistically higher colonization of porcine skins than polystyrene surfaces at $4 \mathrm{~h}$ $(\mathrm{p}<0.001)$ and at $24 \mathrm{~h}(\mathrm{p}<0.05)$, respectively. Application of both single phage Pm5460 and the phage cocktail (phages Pm5460 and Pm5461) on biofilms formed on porcine skins led to only slight decreases in the number of viable cells at $4 \mathrm{~h}$ of infection $(<0.65 \mathrm{log}$ $\mathrm{CFU} \cdot \mathrm{cm}^{-2}$ ) (Fig. 5). At $24 \mathrm{~h}$ of infection, biofilm cells were better reduced using phage Pm5460 alone (1.0 log $\mathrm{CFU} \cdot \mathrm{cm}^{-2}$ reduction), however, this reduction was not statistically significant $(p>0.05)$ compared to the one obtained using the phage cocktail. Contrarily to all other phage-host systems studied, phages were more efficient in reducing biofilms at $4 \mathrm{~h}$ from polystyrene surfaces, resulting in 1.0 and 1.8 $\log \mathrm{CFU} \cdot \mathrm{cm}^{-2}$ lower levels of cells using the single and cocktail phage solutions, respectively, when compared to the controls. However, prolonging the treatment to $24 \mathrm{~h}$ resulted in an increase of viable cells to levels similar to the ones observed in the control samples.

\subsection{Microscopy imaging of biofilms formed on porcine skin sections and polystyrene}

Epifluorescence microscopy imaging was performed after PNA-FISH or LNA-FISH procedures using specific probes (Table S5). Both porcine skins and polystyrene after their in vitro contamination with bacteria (Figs. 6 and 7) were visualized.

Thin micrometre sections, that were 3 to $5 \mu \mathrm{m}$ thick covering samples from the $3.5 \mathrm{~mm}$ wide biopsy punch area of porcine skins, confirmed that cells adhered to these surfaces and were found living in biofilm communities. Portions of biofilms were found attached 


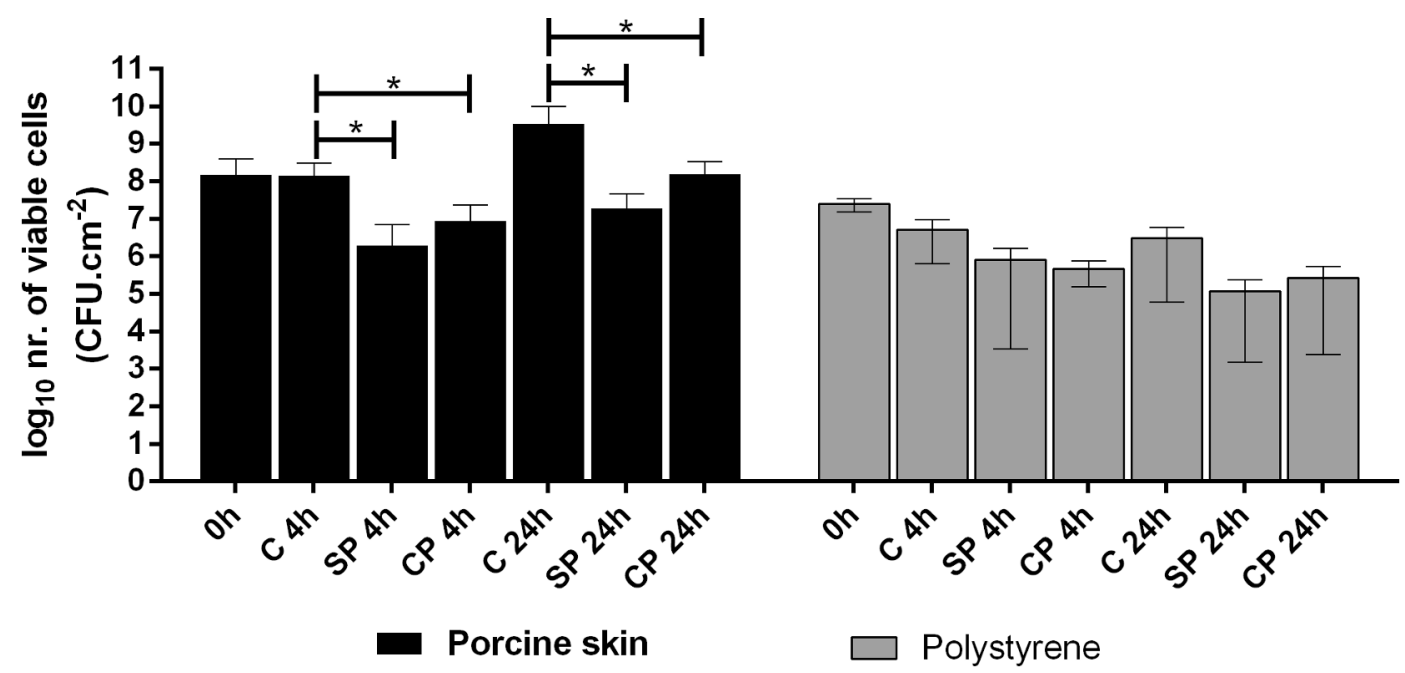

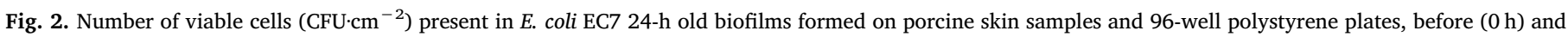
after exposure to single phages or to the phage cocktail for 4 and $24 \mathrm{~h}$. C - control; SP - single phage; CP - cocktail of phages.

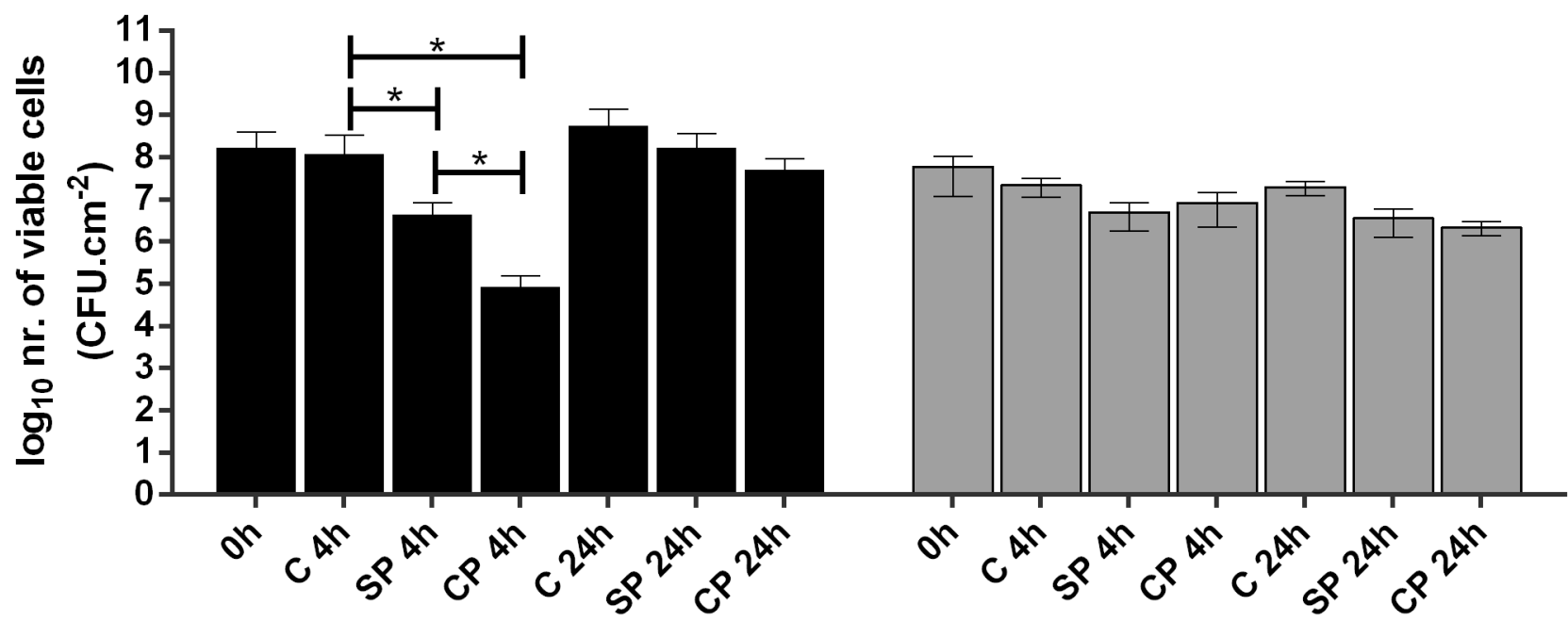

\section{Porcine skin}

\section{Polystyrene}

Fig. 3. Number of viable cells ( $\mathrm{CFU} \cdot \mathrm{cm}^{-2}$ ) present in A. baumannii AB2 24-h biofilms formed on porcine skin samples and 96-well polystyrene plates, before ( $\left.0 \mathrm{~h}\right)$ and after exposure to single phages or to the phage cocktail for 4 and $24 \mathrm{~h}$. C - control; SP - single phage; CP - cocktail of phages.

particularly to the irregularities of porcine skins as observed in the microscopy sections. The $P$. aeruginosa skin sections analysed after LNA2'-OMe-FISH showed only a few rod shaped cells that seemed to be more located in the EPS matrix than actually adhered to the skins (please see Fig. 7C and Fig. S4), and therefore this made analysis more difficult since no large clusters (as observed in Fig. 7A, B and D) were present. Additional porcine skin sections are provided in Figs. S2-S5.

Microscopy imaging of polystyrene surfaces corroborate that $E$. coli is the pathogen that forms biofilms with less cells present (Fig. 7). These cells are dispersed in the surfaces and in some small areas cells were found aggregated in microcolonies, (Fig. 7A). A. baumannii cells were stained in red due to the Cy5 conjugated to the probe used. Sample areas analysed showed differences in colonization with some areas more heavily colonized, presenting apparently different layers, and other areas that had cells sparsely distributed, and even some proportions of the surface that had no cells attached (Fig. 7B and Fig. S7). Biofilms of $P$. aeruginosa tended to aggregate in specific areas leaving other areas completely uncontaminated (Fig. 7C and Fig. S8). Biofilm cells of $P$. mirabilis were dispersed throughout the surface and appeared to be present in different layers since only some appeared focused while others only appeared focused when the working distance between sample and objectives were changed (Fig. 7D and Fig. S9). Additional microscopy images of the surfaces are also provided as Supplementary Material (see Figs. S6-S9).

\section{Discussion}

Although the potential of phage therapy has been well demonstrated in the last years (Chhibber et al., 2013; Mendes et al., 2013; Seth et al., 2013), limited studies have been reported using ex vivo models. In vitro models using abiotic surfaces are easily reproducible but may not accurately reflect the efficacy of antimicrobial compounds on, for instance, biofilms found in wounds (Yang et al., 2013). A better approach to produce biofilms that more closely resemble the characteristics of biofilms found in wounds can rely on the use of pig skin as the attachment surface as well as the primary source of nutrients. The porcine skin ex vivo model includes valuable characteristics such similarity with human skin anatomy and physiology, and the fact that it is suitable for several trials at an affordable price (Schmook et al., 2001; Sullivan et al., 2001). 


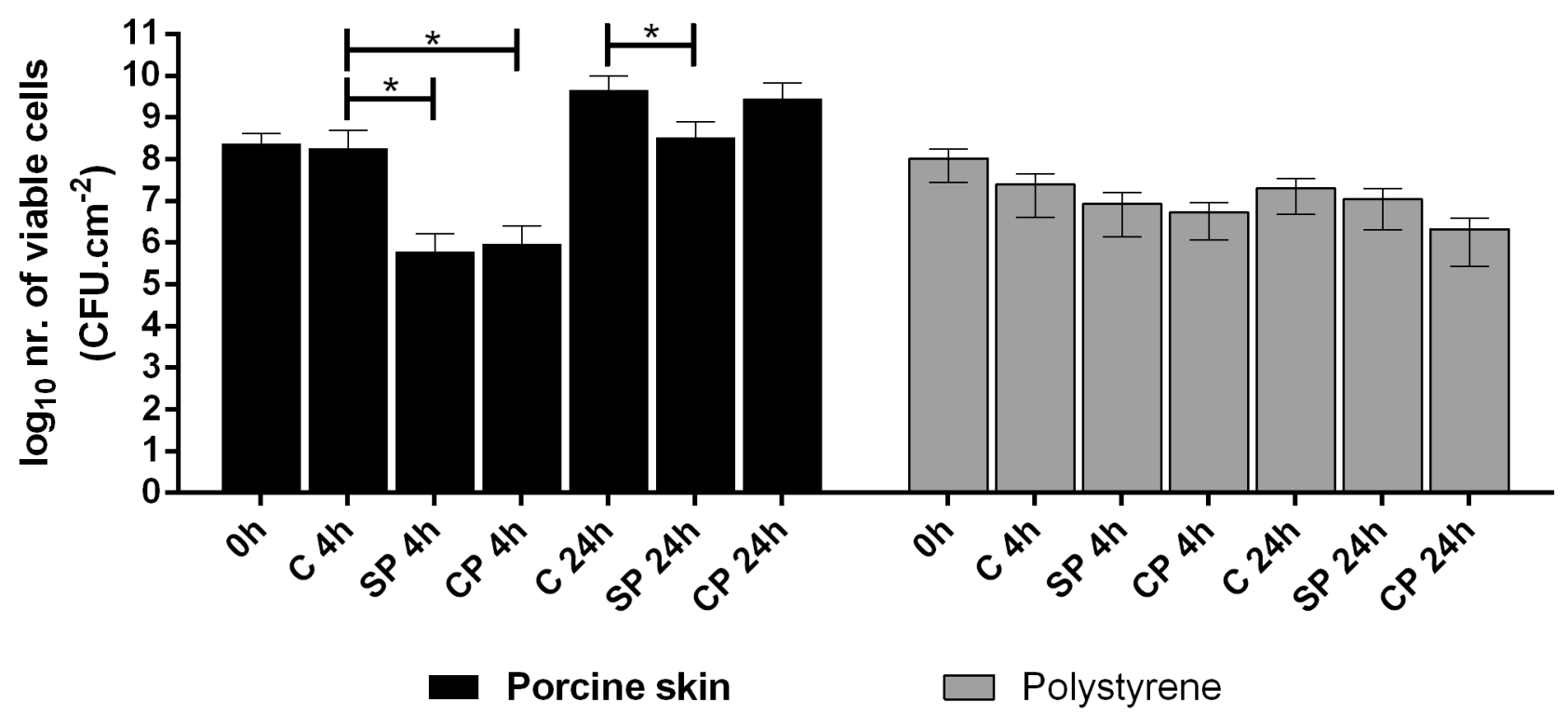

Fig. 4. Number of viable cells $\left(\mathrm{CFU} \cdot \mathrm{cm}^{-2}\right)$ present in P. aeruginosa PA1 24-h biofilms formed on porcine skin samples and 96-well polystyrene plates, before $(0 \mathrm{~h})$ and after exposure to single phages or to the phage cocktail for 4 and $24 \mathrm{~h}$. C - control; SP - single phage; CP - cocktail of phages.

In a previous work, we reported the use of phages in an ex vivo model where biofilms were also formed in porcine skins (Oliveira et al., 2018). However, there are major differences between this model and the one used in the present work (see Fig. 1 and Fig. S1). In our previous study, we used a model that more closely mimics a mild abrasion wound since no injuries were made on the porcine skin surfaces (Fig. S1). In the model presented herein, a cavity was created in the porcine skins to allow biofilm formation in depth, emulating more truthfully contaminated and heavily contaminated wounds (Fig. 1).

The results obtained with the ex vivo model used herein were also compared with biofilms formed in vitro (polystyrene plates). The phages used target pathogens frequently found associated to wound infections. These include two pathogens ( $A$. baumannii and $P$. aeruginosa) of the ESKAPE (Enterococcus faecium, Staphylococcus aureus, Klebsiella pneumoniae, Acinetobacter baumannii, Pseudomonas aeruginosa, and Enterobacter species) group - the leading group of pathogens involved in nosocomial infections worldwide. This study also includes two Enterobacteriaceae (E. coli and P. mirabilis). Bacteria from this family have become increasingly more resistant to carbapenem and carbapenem-resistant Enterobacteriaceae (CRE) are, according to CDC responsible for the death in up to $50 \%$ of patients who become infected (CDC, 2018). In 2017, the World Health Organization (WHO) listed a priority list of pathogens to ensure research and development of new antibiotics for 12 families of bacteria that pose the greatest threat to human health. In this list, first priority or critical priority, as described by WHO, is needed for:1) A. baumannii, 2) P. aeruginosa, and 3) Enterobacteriaceae, CRE, extended-spectrum beta-lactamases (ESBL) producing bacteria (WHO, 2017). Despite the polymicrobial aetiology of

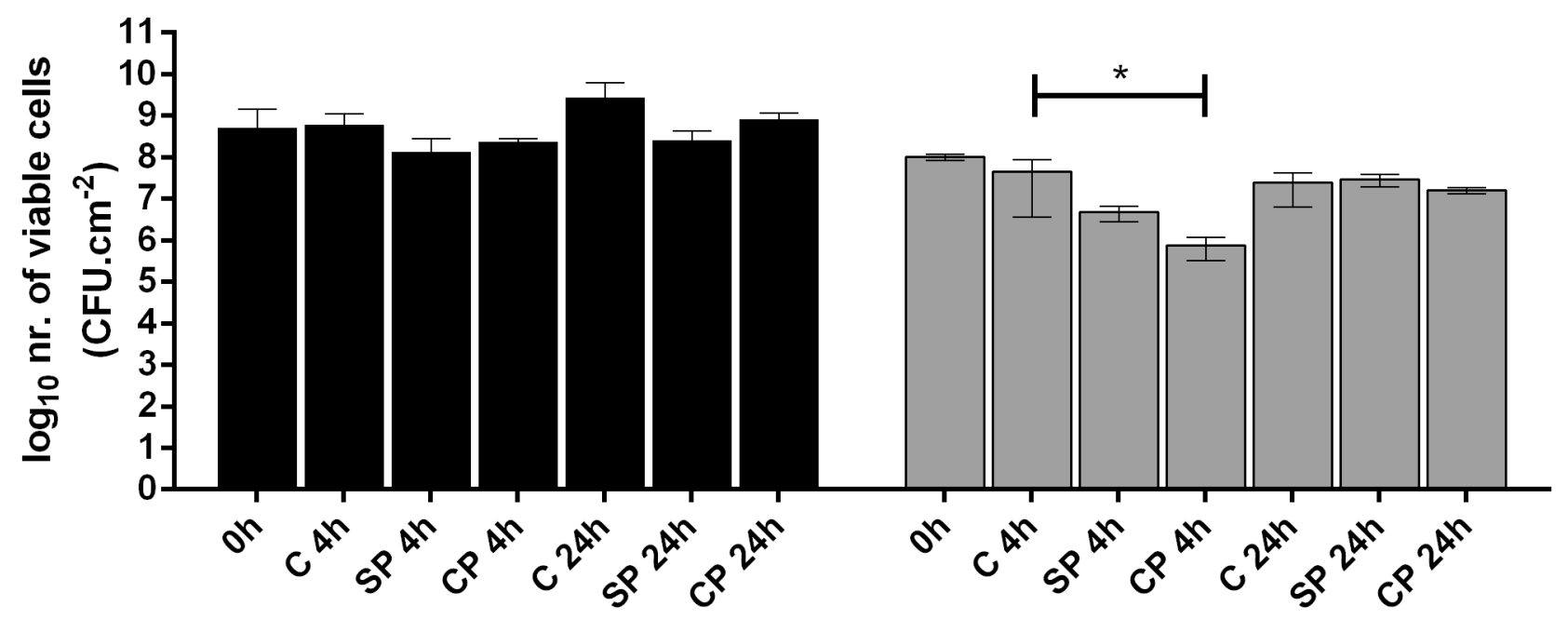

\section{Porcine skin}

Polystyrene

Fig. 5. Number of viable cells (CFU. $\mathrm{cm}^{-2}$ ) present in P. mirabilis 5460 24-h biofilms formed on porcine skin samples and 96 -well polystyrene plates, before $(0 \mathrm{~h})$ and after exposure to single phages or to the phage cocktail for 4 and $24 \mathrm{~h}$. C - control; SP - single phage; CP - cocktail of phages. 

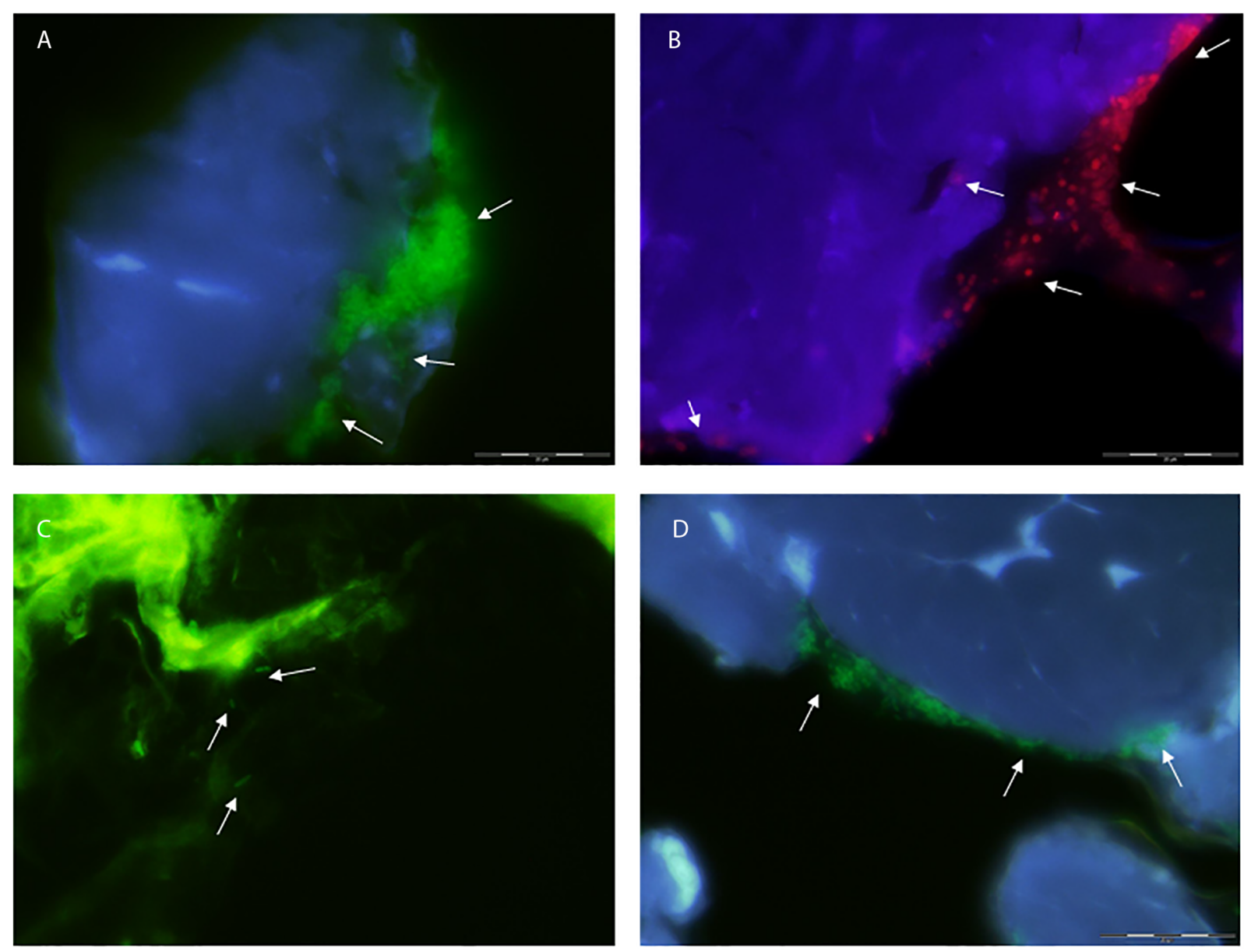

Fig. 6. Microscopy imaging of histological porcine skin sections colonized with the different pathogens stained with the probes described in Table S5. (A) E. coli EC7, (B) A. baumannii AB2, (C) P. aeruginosa PAO1, (D) P. mirabilis 5460. Skin tissues were stained with DAPI. Scale bar corresponds to $20 \mu \mathrm{m}$. $P$. aeruginosa micrographs do not present a scale bar but images were taken using the same amplification.

chronic wound infections (Frank et al., 2009), only monospecies biofilm populations of these four pathogens were investigated to simplify specimen processing and data analysis.

It is a known fact that the surface chosen for biofilm formation has influence in the biofilm structure, physiology and composition (Nadell et al., 2016; Qi et al., 2018), and also in gene expression (PrigentCombaret et al., 1999; Ren et al., 2004; Southey-Pillig et al., 2005). The colonization of the two studied surfaces varied greatly and pathogen loads were always superior on the biological surface (porcine skins) than on polystyrene. Hydrophobicity of surfaces can promote/decrease cell attachment (Katsikogianni and Missirlis, 2004). Both surfaces tested herein are hydrophobic, having similar water contact angles, with porcine skins exhibiting an angle of $91^{\circ}$ (Elkhyat et al., 2004), and polystyrene angles between $90^{\circ}$ and $94^{\circ}$ (Bekele and Tsige, 2013; Bergslien et al., 2004). The use of polystyrene for biofilm growth can only be used for nonaffixing cells such as bacteria (Curtis et al., 1983; Dowling et al., 2011). In our experiments, cell colonization of porcine skins could possibly be enhanced due to the nutrients provided by the skin itself but also due to the greater roughness that increases the overall surface area for colonisation as confirmed by the location of microbial biofilm formation in the histological porcine skin sections assessed by microscopy (Fig. 6). The differences in biofilm formation may interfere in the interaction of phages with their host bacteria since it appears that biofilm cells in porcine skin explants are closer and this might enhance their elimination by phages.

Due to the difference in surface colonization, and in order to allow comparisons, not only between species but also between surfaces tested, the ratio of phage to host was always maintained constant regardless of the surface tested - the MOI was 100 for the phage applied alone and this MOI was also kept for this phage when applied in the cocktail together with other phage(s) that was(were) added at a MOI of 1 . As already expected, phages were able to reduce more viable cells after $4 \mathrm{~h}$ than at $24 \mathrm{~h}$, corroborating previous studies using other phages and their hosts (Carson et al., 2010; Melo et al., 2016; Pires et al., 2011). Reductions at $4 \mathrm{~h}$ using a single phage on biofilms formed on porcine skins varied from $0.64 \mathrm{log} \mathrm{CFU} \cdot \mathrm{cm}^{-2}$ (P. mirabilis) to $2.48 \mathrm{log}$ CFU $\cdot \mathrm{cm}^{-2}$ ( $P$. aeruginosa), while the combination of phages (2 or 3 phages) resulted in viable cell reductions in the range of $0.41 \mathrm{log}$ $\mathrm{CFU} \cdot \mathrm{cm}^{-2}$ ( $P$. mirabilis) to $2.30 \log \mathrm{CFU} \cdot \mathrm{cm}^{-2}$ ( $P$. aeruginosa). The increase of treatment time was only beneficial for $E$. coli where the phages continued to decrease the number of viable cells, particularly in the experiments carried out using the ex vivo model. The efficacy of phages against $E$. coli biofilms formed in vitro was overall lower than ex vivo, despite using the same initial MOIs (adjusted to the initial viable cell concentration of the biofilms that was optimized prior to phage application studies). The use of a phage cocktail was not much different than using phage alone. It was expected that the presence of a phage possessing depolymerase activity, such as EC3a that is present in the E. coli phage cocktail, would grant a final higher effect on viable cells but this was not the case. This result was expected since phages encoding depolymerases are described to have a better access to the host receptors due to degradation of the EPS that not only increases cell death but also promotes phage diffusion to other layers of the biofilm (Pires et al., 2016).

The greatest differences towards control of biofilms formed in vitro and ex vivo were perceived after $4 \mathrm{~h}$ using $E$. coli, A. baumannii, and $P$. 

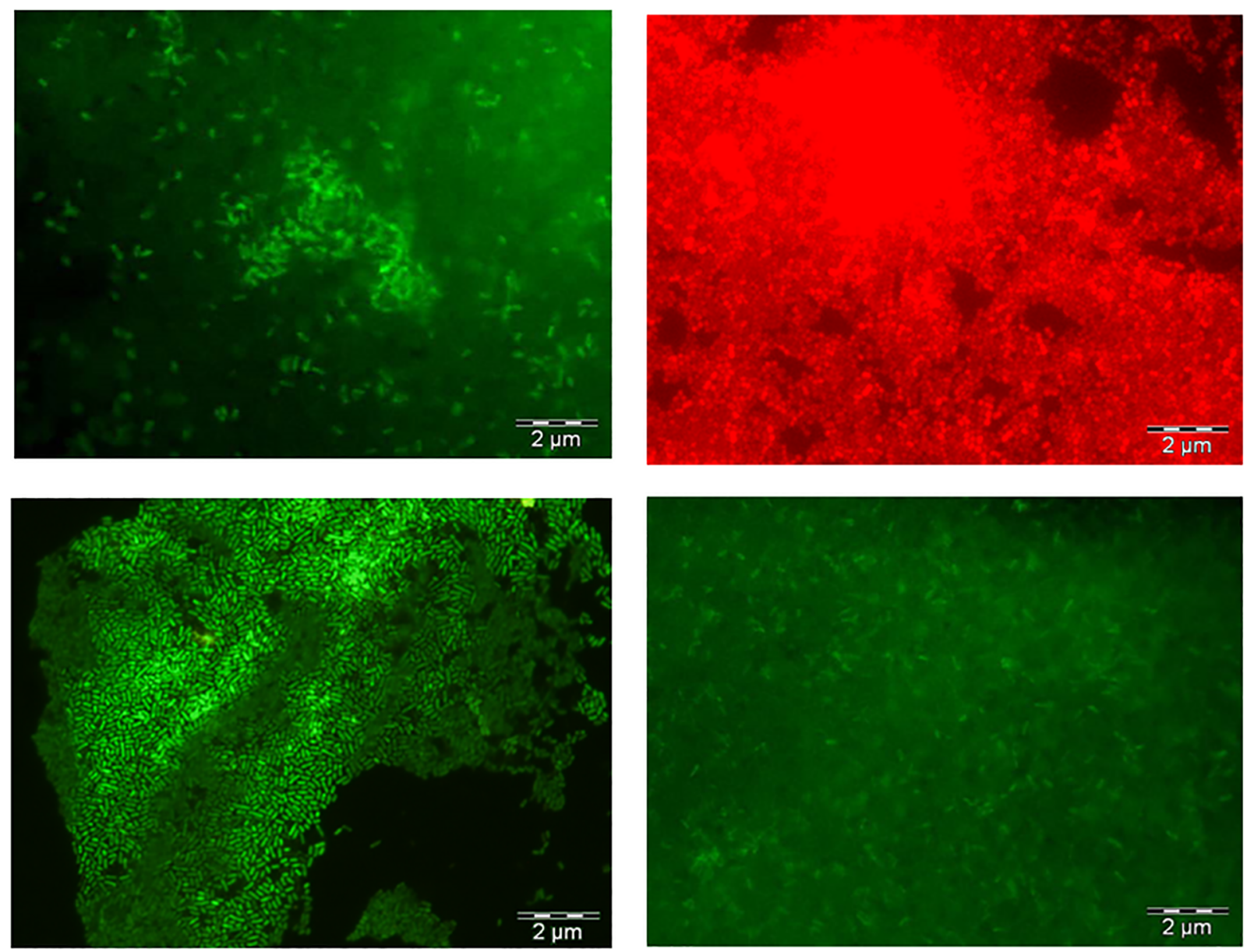

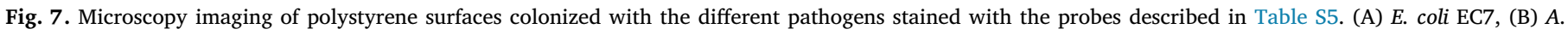
baumannii AB2, (C) P. aeruginosa PAO1, (D) P. mirabilis 5460. Scale bar corresponds to $2 \mu \mathrm{m}$.

aeruginosa phages. In these samples phages were able to reduce higher numbers of cells from porcine skins than from polystyrene. The most similar effect of phages against biofilms formed in both surfaces was obtained using $E$. coli phages which in general reduced above $1.0 \mathrm{log}$ $\mathrm{CFU} \cdot \mathrm{cm}^{-2}$ of biofilm cells. The only species where phages showed slightly better efficacy in vitro than ex vivo, particularly after $4 \mathrm{~h}$, was $P$. mirabilis. These contrasting/similar results may be due to the differences/similarities in biofilm structure and composition, and amount of EPS matrix present in the biofilms formed in these two surfaces. For instance, when the level of EPS increases this may compromise phage recognition of the host through masking of its receptors.Further experiments need to be performed to validate this hypothesis. In the case of $P$. mirabilis, besides biofilm structure and composition, there may also be differences in swarming ability of this bacterium in the two surfaces. It has been previously described that $P$. mirabilis swarming ability changed simply by changing the type of catheter that served as surface for cell adhesion (Hola et al., 2012). These authors tested 102 Proteus isolates and showed greatest swarming when Kendall Cathetertype Curity catheters were used (91.2\%), while worst swarming was on Meditec Foley catheters (2\%). Swarming is a flagella-driven surface migration behaviour that confers bacteria capacity to rapidly colonize nutritionally rich environments, such as porcine skin, facilitating colony spread and accelerating biomass production (Rather, 2005) to form crystalline biofilms which may prevent phage adsorption to the host receptors (Melo et al., 2016). According to a previous study, swarming of Proteus spp. compromised phages diffusion through biofilm matrix (Carson et al., 2010), leading to a more difficult killing ability of phages. These studies corroborate our findings that Proteus biofilms formed on porcine skins have possibly better swarming conditions than in polystyrene and therefore we observed better phage activity in the latter surface.

In theory, the reductions caused by phages can be further increased in in vivo conditions due to the innate immune response which will work synergistically with phages to eliminate bacteria as demonstrated previously through a mechanism described as immunophage synergy (Hodyra-Stefaniak et al., 2015; Leung and Weitz, 2017; Roach et al., 2017). Roach et al. (2017) showed that neutrophil-phage synergy is essential for the resolution of pneumonia being neutrophils involved in clearing in vivo phage susceptible and phage resistant variants, that phages were immunologically well tolerated and that phages were not cleared by immune effector cells.

\section{Conclusions}

In summary, some of the phages isolated and tested in this work significantly impaired biofilm formation of several pathogens in a model which mimics an infected open wounds, highlighting their potential as alternative or complementary treatment agents to control wound infections.

\section{Funding}

This work was supported by Portuguese Foundation for Science and Technology under the scope of the strategic funding of UID/BIO/ 04469/2013 unit and COMPETE 2020 (POCI-01-0145-FEDER-006684) and BioTecNorte operation (NORTE-01-0145-FEDER-000004) funded by the European Regional Development Fund under the scope of Norte2020 - Programa Operacional Regional do Norte and the Project 
RECI/BBB-EBI/0179/2012 (FCOMP-01-0124-FEDER-027462). CM acknowledges the Portuguese Foundation for Science and Technology (FCT) grant SFRH/BD/94434/2013. SS is an Investigador FCT (IF/ 01413/2013).

\section{Conflict of interest statement}

The authors declare that the research was conducted in the absence of any commercial or financial relationships that could be construed as a potential conflict of interest.

\section{Appendix A. Supplementary data}

Supplementary data to this article can be found online at https:// doi.org/10.1016/j.ijpharm.2018.12.004.

\section{References}

Adams, M., 1959. Bacteriophages. Interscience Publishers Inc., New York.

Almeida, C., Azevedo, N.F., Iversen, C., Fanning, S., Keevil, C.W., Vieira, M.J., 2009. Development and application of a novel peptide nucleic acid probe for the specific detection of Cronobacter Genomospecies (Enterobacter sakazakii) in powdered infan formula. Appl. Environ. Microbiol. 75, 2925-2930. https://doi.org/10.1128/AEM. 02470-08.

Alves, D.R., Booth, S.P., Scavone, P., Schellenberger, P., Salvage, J., Dedi, C., Thet, N.-T., Jenkins, A.T.A., Waters, R., Ng, K.W., Overall, A.D.J., Metcalfe, A.D., Nzakizwanayo, J., Jones, B.V., 2018. Development of a high-throughput ex-vivo burn wound model using porcine skin, and its application to evaluate new approaches to control wound infection. Front. Cell. Infect. Microbiol. 8, 1-15. https://doi.org/10.3389/fcimb. 2018.00196.

Ammons, M., 2010. Anti-biofilm strategies and the need for innovations in wound care. Recent Pat. Antiinfect. Drug Discov. 5, 10-17. https://doi.org/10.2174/ 157489110790112581.

Bekele, S., Tsige, M., 2013. Interfacial properties of oxidized polystyrene and its interaction with water. Langmuir 29, 13230-13238. https://doi.org/10.1021/la403099e.

Bergslien, E., Fountain, J., Giese, R., 2004. Characterization of the surface properties of epoxy-type models used for multiphase flow studies in fractured media and creation of a new model. Water Resour. Res. 40,1-11. https://doi.org/10.1029/ 2003WR002780.

Carson, L., Gorman, S.P., Gilmore, B.F., 2010. The use of lytic bacteriophages in the prevention and eradication of biofilms of Proteus mirabilis and Escherichia coli. FEMS Immunol. Med. Microbiol. 59, 447-455. https://doi.org/10.1111/j.1574-695X.2010. 00696.x.

CDC, 2018. Carbapenem-resistant Enterobacteriaceae in Healthcare Settings [WWW Document]. Heal. Infect. URL https://www.cdc.gov/HAI/organisms/cre/ (accessed 11.9.18).

Cerqueira, L., Fernandes, R.M., Ferreira, R.M., Carneiro, F., Dinis-Ribeiro, M., Figueiredo, C., Keevil, C.W., Azevedo, N.F., Vieira, M.J., 2011. PNA-FISH as a new diagnostic method for the determination of clarithromycin resistance of Helicobacter pylori. BMC Microbiol. 11, 101. https://doi.org/10.1186/1471-2180-11-101.

Chhibber, S., Kaur, T., Kaur, Sandeep, 2013. Co-therapy using lytic bacteriophage and linezolid: effective Treatment in eliminating methicillin Resistant Staphylococcus aureus (MRSA) from diabetic foot infections. PLoS One 8, e56022. https://doi.org/10. 1371/journal.pone.0056022.

Curtis, A.S.G., Forrester, J.V., Mclnnes, C., Lawrie, F., 1983. Adhesion of cells to polystyrene surfaces. J. Cell Biol. 97, 1500-1506.

Da Costa, A., Machado, R., Ribeiro, A., Collins, T., Thiagarajan, V., Neves-Petersen, M.T., Rodriguez-Cabello, J.C., Gomes, A.C., Casal, M., 2015. Development of elastin-like recombinamer films with antimicrobial activity. Biomacromolecules 16. https://doi. org/10.1021/bm5016706.

Dowling, D.P., Miller, I.S., Ardhaoui, M., Gallagher, W.M., 2011. Effect of surface wettability and topography on the adhesion of osteosarcoma cells on plasma-modified polystyrene. J. Biomater. Appl. 26, 327-347. https://doi.org/10.1177/ 0885328210372148.

Elkhyat, A., Courderot-Masuyer, C., Gharbi, T., Humbert, P., 2004. Influence of the hydrophobic and hydrophilic characteristics of sliding and slider surfaces on friction coefficient: in vivo human skin friction comparison. Ski. Res. Technol. 10, 215-221. https://doi.org/10.1111/j.1600-0846.2004.00085.x.

Frank, D.N., Wysocki, A., Specht-Glick, D.D., Rooney, A., Feldman, R.A., St. Amand, A.L., Pace, N.R., Trent, J.D., 2009. Microbial diversity in chronic open wounds. Wound Repair Regen. 17, 163-172. https://doi.org/10.1111/j.1524-475X.2009.00472.x.

Fux, C., Costerton, J., Stewart, P., Stoodley, P., 2005. Survival strategies of infectious biofilms. Trends Microbiol. 13, 34-40. https://doi.org/10.1016/j.tim.2004.11.010.

Ganesh, K., Sinha, M., Mathew-Steiner, S.S., Das, A., Roy, S., Sen, C.K., 2015. Chronic wound biofilm model. Adv. Wound Care 4, 382-388. https://doi.org/10.1089/ wound.2014.0587.

Gjødsbøl, K., Christensen, J.J., Karlsmark, T., Jørgensen, B., Klein, B.M., Krogfelt, K.A., 2006. Multiple bacterial species reside in chronic wounds: a longitudinal study. Int. Wound J. 3, 225-231. https://doi.org/10.1111/j.1742-481X.2006.00159.x.

Gooderham, W.J., Hancock, R.E.W., 2009. Regulation of virulence and antibiotic resistance by two-component regulatory systems in Pseudomonas aeruginosa. FEMS Microbiol. Rev. 33, 279-294. https://doi.org/10.1111/j.1574-6976.2008.00135.x.

Górski, A., Międzybrodzki, R., Weber-Dąbrowska, B., Fortuna, W., Letkiewicz, S., Rogóż, P., Jończyk-Matysiak, E., Dąbrowska, K., Majewska, J., Borysowski, J., 2016. Phage therapy: combating infections with potential for evolving from merely a treatment for complications to targeting diseases. Front. Microbiol. 7, 1515. https://doi.org/10. 3389/fmicb.2016.01515.

Gottrup, F., 2004. A specialized wound-healing center concept: importance of a multidisciplinary department structure and surgical treatment facilities in the treatment of chronic wounds. Am. J. Surg. 187, 38S-43S. https://doi.org/10.1016/S00029610(03)00303-9.

Hall-Stoodley, L., Stoodley, P., 2009. Evolving concepts in biofilm infections. Cell. Microbiol. 11, 1034-1043. https://doi.org/10.1111/j.1462-5822.2009.01323.x.

Hodyra-Stefaniak, K., Miernikiewicz, P., Drapała, J., Drab, M., Jończyk-Matysiak, E. Lecion, D., Kaźmierczak, Z., Beta, W., Majewska, J., Harhala, M., Bubak, B., Kłopot, A., Górski, A., Dabrowska, K., 2015. Mammalian host-versus-phage immune response determines phage fate in vivo. Sci. Rep. 5, 14802. https://doi.org/10.1038/ srep14802.

Hola, V., Peroutkova, T., Ruzicka, F., 2012. Virulence factors in Proteus bacteria from biofilm communities of catheter-associated urinary tract infections. FEMS Immunol. Med. Microbiol. 65, 343-349. https://doi.org/10.1111/j.1574-695X.2012.00976.x.

Katsikogianni, M., Missirlis, Y., 2004. Concise review of mechanisms of bacterial adhesion to biomaterials and of techniques used in estimating bacteria-material interactions. Eur. Cells Mater. 8, 37-57. https://doi.org/10.22203/eCM.v008a05.

Leung, C., Weitz, J., 2017. Modeling the synergistic elimination of bacteria by phage and the innate immune system. J. Theor. Biol. 429, 241-252. https://doi.org/10.1016/j. jtbi.2017.06.037.

Mascio, C.T.M., Alder, J.D., Silverman, J.A., 2007. Bactericidal action of daptomycin against stationary-phase and nondividing staphylococcus aureus cells. Antimicrob. Agents Chemother. 51, 4255-4260. https://doi.org/10.1128/AAC.00824-07.

Melo, L.D.R., Veiga, P., Cerca, N., Kropinski, A.M., Almeida, C., Azeredo, J., Sillankorva, S., 2016. Development of a phage cocktail to control Proteus mirabilis catheter-associated urinary tract infections. Front. Microbiol. 7, 1-12. https://doi.org/10.3389/ fmicb. 2016.01024.

Mendes, J.J., Leandro, C., Corte-Real, S., Barbosa, R., Cavaco-Silva, P., Melo-Cristino, J., Górski, A., Garcia, M., 2013. Wound healing potential of topical bacteriophage therapy on diabetic cutaneous wounds. Wound Repair Regen. 21, 595-603. https:// doi.org/10.1111/wrr.12056.

Nadell, C.D., Drescher, K., Foster, K.R., 2016. Spatial structure, cooperation and competition in biofilms. Nat. Rev. Microbiol. 14, 589-600. https://doi.org/10.1038/ nrmicro.2016.84.

Neves, F.P.G., Cardoso, N.T., Souza, A.R.V., Snyder, R.E., Marlow, M.M., Pinto, T.C.A., Teixeira, L.M., Riley, L.W., 2018. Population structure of Streptococcus pneumoniae colonizing children before and after universal use of pneumococcal conjugate vaccines in Brazil: emergence and expansion of the MDR serotype 6C-CC386 lineage. J. Antimicrob. Chemother. 73, 1206-1212. https://doi.org/10.1093/jac/dky001.

Oliveira, A., Ribeiro, H.G., Silva, A.C., Silva, M.D., Sousa, J.C., Rodrigues, C.F., Melo, L.D.R., Henriques, A.F., Sillankorva, S., 2017. Synergistic antimicrobial interaction between honey and phage against Escherichia coli biofilms. Front. Microbiol. 8, 1-18. https://doi.org/10.3389/fmicb.2017.02407.

Oliveira, A., Sousa, J.C., Silva, A.C., Melo, L.D.R., Sillankorva, S., 2018. Chestnut honey and bacteriophage application to control Pseudomonas aeruginosa and Escherichia coli biofilms: evaluation in an ex vivo wound model. Front. Microbiol. 9, 1-13. https:// doi.org/10.3389/fmicb.2018.01725.

Oliveira, H., Costa, A.R., Konstantinides, N., Ferreira, A., Akturk, E., Sillankorva, S. Nemec, A., Shneider, M., Dötsch, A., Azeredo, J., 2017. Ability of phages to infect Acinetobacter calcoaceticus-Acinetobacter baumannii complex species through acquisition of different pectate lyase depolymerase domains. Environ. Microbiol. 19, 5060-5077. https://doi.org/10.1111/1462-2920.13970.

Oliveira, H., Sillankorva, S., Merabishvili, M., Kluskens, L.D., Azeredo, J., 2015. Unexploited opportunities for phage therapy. Front. Pharmacol. 6, 1-4. https://doi. org $/ 10.3389 /$ fphar.2015.00180.

Percival, S.L., Hill, K.E., Williams, D.W., Hooper, S.J., Thomas, D.W., Costerton, J.W., 2012. A review of the scientific evidence for biofilms in wounds. Wound Repair Regen. 20, 647-657. https://doi.org/10.1111/j.1524-475X.2012.00836.x.

Pires, D., Melo, L., Vilas Boas, D., Sillankorva, S., Azeredo, J., 2017. Phage therapy as an alternative or complementary strategy to prevent and control biofilm-related infections. Curr. Opin. Microbiol. 39, 48-56. https://doi.org/10.1016/j.mib.2017.09.004.

Pires, D., Sillankorva, S., Faustino, A., Azeredo, J., 2011. Use of newly isolated phages for control of Pseudomonas aeruginosa PAO1 and ATCC 10145 biofilms. Res. Microbiol. 162, 798-806. https://doi.org/10.1016/j.resmic.2011.06.010.

Pires, D.P., Oliveira, H., Melo, L.D.R., Sillankorva, S., Azeredo, J., 2016. Bacteriophageencoded depolymerases: their diversity and biotechnological applications. Appl. Microbiol. Biotechnol. 100, 2141-2151. https://doi.org/10.1007/s00253-0157247-0.

Pires, D.P., Vilas Boas, D., Sillankorva, S., Azeredo, J., 2015. Phage therapy: a step forward in the treatment of Pseudomonas aeruginosa infections. J. Virol. 89, 7449-7456. https://doi.org/10.1128/JVI.00385-15.

Price, L.B., Liu, C.M., Melendez, J.H., Frankel, Y.M., Engelthaler, D., Aziz, M., Bowers, J., Rattray, R., Ravel, J., Kingsley, C., Keim, P.S., Lazarus, G.S., Zenilman, J.M., 2009. Community analysis of chronic wound bacteria using 16S rRNA gene-based pyrosequencing: impact of diabetes and antibiotics on chronic wound microbiota. PLoS One 4, e6462. https://doi.org/10.1371/journal pone.0006462.

Prigent-Combaret, C., Vidal, O., Dorel, C., Lejeune, P., 1999. Abiotic surface sensing and biofilm-dependent regulation of gene expression in Escherichia coli. J. Bacteriol. 181, 5993-6002. 
Qi, M., Liang, B., Chen, R., Sun, X., Li, Z., Ma, X., Zhao, Y., Kong, D., Wang, J., Wang, A., 2018. Effects of surface charge, hydrophilicity and hydrophobicity on functional biocathode catalytic efficiency and community structure. Chemosphere 202, 105-110. https://doi.org/10.1016/j.chemosphere.2018.03.065.

Rather, P.N., 2005. Swarmer cell differentiation in Proteus mirabilis. Environ. Microbiol. 7, 1065-1073. https://doi.org/10.1111/j.1462-2920.2005.00806.x.

Ren, D., Bedzyk, L.A., Thomas, S.M., Ye, R.W., Wood, T.K., 2004. Gene expression in Escherichia coli biofilms. Appl. Microbiol. Biotechnol. 64, 515-524. https://doi.org/ 10.1007/s00253-003-1517-y.

Rhoads, D.D., Cox, S.B., Rees, E.J., Sun, Y., Wolcott, R.D., 2012. Clinical identification of bacteria in human chronic wound infections: culturing vs. 16S ribosomal DNA sequencing. BMC Infect. Dis. 12, 321. https://doi.org/10.1186/1471-2334-12-321.

Roach, D.R., Leung, C.Y., Henry, M., Morello, E., Singh, D., Di Santo, J.P., Weitz, J.S., Debarbieux, L., 2017. Synergy between the host immune system and bacteriophage is essential for successful phage therapy against an acute respiratory pathogen. Cell Host Microbe 22, 38-47.e4. https://doi.org/10.1016/j.chom.2017.06.018.

Sambrook, J., Russel, D.W., 2001. Molecular Cloning: A Laboratory Manual, third ed. Cold Spring Harbor Laboratory Press, Cold Spring Harbor, NY, USA.

Schmook, F.P., Meingassner, J.G., Billich, A., 2001. Comparison of human skin or epidermis models with human and animal skin in in-vitro percutaneous absorption. Int. J. Pharm. 215, 51-56. https://doi.org/10.1016/S0378-5173(00)00665-7.

Seaton, M., Hocking, A., Gibran, N.S., 2015. Porcine models of cutaneous wound healing. ILAR J. 56, 127-138. https://doi.org/10.1093/ilar/ilv016.

Sen, C.K., Gordillo, G.M., Roy, S., Kirsner, R., Lambert, L., Hunt, T.K., Gottrup, F., Gurtner, G.C., Longaker, M.T., 2009. Human skin wounds: a major and snowballing threat to public health and the economy. Wound Repair Regen. 17, 763-771. https:// doi.org/10.1111/j.1524-475X.2009.00543.x.

Seth, A.K., Geringer, M.R., Nguyen, K.T., Agnew, S.P., Dumanian, Z., Galiano, R.D., Leung, K.P., Mustoe, T.A., Hong, S.J., 2013. Bacteriophage therapy for Staphylococcus aureus biofilm-infected wounds. Plast. Reconstr. Surg. 131, 225-234. https://doi.org/ 10.1097/PRS.0b013e31827e47cd.

Sillankorva, S., Azeredo, J., 2014. The use of bacteriophages and bacteriophage-derived enzymes for clinically relevant biofilm control. In: Borysowski, J., Międzybrodzki, R., Górski, A. (Eds.), Phage Therapy: Current Research and Applications. Caister Academic Press, Norfolk, UK, pp. 305-325.

Sillankorva, S., Neubauer, P., Azeredo, J., 2008a. Pseudomonas fluorescens biofilms subjected to phage phiIBB-PF7A. BMC Biotech. 8. https://doi.org/10.1186/14726750-8-79.

Sillankorva, S., Neubauer, P., Azeredo, J., 2008b. Isolation and characterization of a T7like lytic phage for Pseudomonas fluorescens. BMC Biotech. 8, 1-11. https://doi.org/ 10.1186/1472-6750-8-80.

Sillankorva, S., Pleteneva, E., Shaburova, O., Santos, S., Carvalho, C., Azeredo, J., Krylov, V., 2010. Salmonella Enteritidis bacteriophage candidates for phage therapy of poultry. J. Appl. Microbiol. 108, 1175-1186. https://doi.org/10.1111/j.1365-2672. 2009.04549.x.

Southey-Pillig, C.J., Davies, D.G., Sauer, K., 2005. Characterization of temporal protein production in Pseudomonas aeruginosa biofilms. J. Bacteriol. 187, 8114-8126. https://doi.org/10.1128/JB.187.23.8114-8126.2005.

Stewart, P.S., William Costerton, J., 2001. Antibiotic resistance of bacteria in biofilms. Lancet 358, 135-138. https://doi.org/10.1016/S0140-6736(01)05321-1.

Sullivan, T.P., Eaglstein, W.H., Davis, S.C., Mertz, P., 2001. The pig as a model for human wound healing. Wound Repair Regen. 9, 66-76. https://doi.org/10.1046/j.1524475x.2001.00066.x.

Thevanesam, V., 2013. Chronic wounds and their management and application in a contemporary Sri Lankan hospital setting. Sri Lankan J. Infect. Dis. 3, 2-16. https:// doi.org/10.4038/sljid.v3i2.5974.

Vilas Boas, D., Almeida, C., Sillankorva, S., Nicolau, A., Azeredo, J., Azevedo, N.F., 2016. Discrimination of bacteriophage infected cells using locked nucleic acid fluorescent in situ hybridization (LNA-FISH). Biofouling 32, 179-190. https://doi.org/10.1080/ 08927014.2015.1131821.

WHO, 2017. WHO publishes list of bacteria for which new antibiotics are urgently needed [WWW Document]. accessed 11.9.18. http://www.who.int/en/news-room/detail/ 27-02-2017-who-publishes-list-of-bacteria-for-which-new-antibiotics-are-urgentlyneeded.

Wolcott, R., Cutting, K., Ruiz, J., 2008a. Advancing your practice: understanding wound infection and the role of biofilms. Assoc. Adv. Wound Care 12-17.

Wolcott, R., Rhoads, D., Dowd, S., 2008b. Biofilms and chronic wound inflammation. J. Wound Care 17, 333-341. https://doi.org/10.12968/jowc.2008.17.8.30796.

Yang, Q., Phillips, P.L., Sampson, E.M., Progulske-Fox, A., Jin, S., Antonelli, P., Schultz, G.S., 2013. Development of a novel ex vivo porcine skin explant model for the assessment of mature bacterial biofilms. Wound Repair Regen. 21, 704-714. https:// doi.org/10.1111/wrr.12074. 